\title{
Reasons for non-participation in a randomised controlled trial and the effect of audiovisual material
}

\author{
Neil Nathwani", Amanda Davis, Evgenia Konstantakopoulou, Gus Gazzard, LiGHT Trial Research Group \\ From 3rd International Clinical Trials Methodology Conference \\ Glasgow, UK. 16-17 November 2015
}

\section{Background}

Recruitment in randomised controlled trials (RCT) has been the topic of research for many years. This study, nested within the NIHR Laser in Glaucoma and Ocular Hypertension (LiGHT) Trial, looks into the main reasons for non-participation in a Trial investigating the quality of life and cost-effectiveness of two established glaucoma treatments, and whether the use of audiovisual material (video) improves recruitment rates.

\section{Methods}

Prospective participants to the LiGHT Trial were approached by a member of the research team and were given an explanation of the Trial. Patients who refused to participate were asked to explain the reason for their refusal choosing from a pre-populated list of 12 items and were also given the option to add other reasons. Fifteen months into the Trial a video was also used to facilitate recruitment. The material of the video was the same as delivered by the recruiting team, but was delivered by the Principal Investigator (PI).

\section{Results}

Preliminary data indicate that the overall non-participation rate is $14.2 \%$. The most common reasons for nonparticipation are treatment preconceptions $(63.5 \%)$ and unwillingness to participate in research (25.4\%). A minority of patients chose to have no treatment at all (6.3\%). Incorporation of the video significantly reduced refusal rates from $21.1 \%$ to $8.5 \%(\mathrm{p}<0.01)$.

Moorfields Eye Hospital, London, UK original work is properly cited. The Creative Commons Public Domain Dedication waiver (http://creativecommons.org/publicdomain/ zero/1.0/) applies to the data made available in this article, unless otherwise stated.

\section{Conclusion}

Treatment preconceptions are the predominant reason non-participation in a RCT. Incorporation of the video significantly reduced non-participation rates; it is possible that the involvement of the PI might have a positive effect on recruitment.

Published: 16 November 2015

doi:10.1186/1745-6215-16-S2-P112 randomised controlled trial and the effect of audiovisual material. Trials 2015 16(Suppl 2):P112.
Cite this article as: Nathwani et al:: Reasons for non-participation in a
Submit your next manuscript to BioMed Central and take full advantage of:

- Convenient online submission

- Thorough peer review

- No space constraints or color figure charges

- Immediate publication on acceptance

- Inclusion in PubMed, CAS, Scopus and Google Scholar

- Research which is freely available for redistribution

Submit your manuscript at
www.biomedcentral.com/submit

C Biomed Central \\ () Biomed Central}

